Relations industrielles

Industrial Relations

\title{
John T. ADDISON, John BURTON : Trade Unions and Society. Vancouver, The Fraser Institute, 1984, 189 pp., ISBN 0-88975-056-4
}

\section{Peter E. Larson}

Volume 40, numéro 1, 1985

URI : https://id.erudit.org/iderudit/050119ar

DOI : https://doi.org/10.7202/050119ar

Aller au sommaire du numéro

Éditeur(s)

Département des relations industrielles de l'Université Laval

ISSN

0034-379X (imprimé)

1703-8138 (numérique)

Découvrir la revue

Citer ce compte rendu

Larson, P. E. (1985). Compte rendu de [John T. ADDISON, John BURTON : Trade Unions and Society. Vancouver, The Fraser Institute, 1984, 189 pp., ISBN 0-88975-056-4]. Relations industrielles / Industrial Relations, 40(1), 180-181. https://doi.org/10.7202/050119ar

Tous droits réservés @ Département des relations industrielles de l'Université Laval, 1985
Ce document est protégé par la loi sur le droit d'auteur. L'utilisation des services d'Érudit (y compris la reproduction) est assujettie à sa politique d'utilisation que vous pouvez consulter en ligne.

https://apropos.erudit.org/fr/usagers/politique-dutilisation/ 
Si certains des aspects de ce droit au niveau de l'entreprise, pour innovateurs qu'ils soient dans leur pays d'application, n'étonneront pas outre mesure le lecteur nord-américain - on songe, par exemple, à l'institution de la négociation collective obligatoire avec le chef d'entreprise, ou encore, à la réintégration du représentant syndical irrégulièrement congédié - il convient néanmoins d'observer qu'ils se greffent à un système dans lequel l'action syndicale s'est traditionnellement affirmée à des niveaux supérieurs, dimension qui semble passablement absente de la réalité d'ici.

Pierre VERGE

Université Laval

Trade Unions and Society, by John T. Addison and John Burton, Vancouver, B.C., The Fraser Institute, 1984, 189 pp., ISBN 0-88975-056-4

In the preface to this third volume of the Fraser Institute's Labour Market series, the Institute's director, Michael Walker indicates that an earlier draft of the same book was entitled «Trade Unions and the British Disease». While the authors finally rejected that title in favour of the present one because they wanted to underline the broader implications of the British experience, it would in some ways have been a more accurate rendition of the contents.

Based primarily on an analysis of the British experience, Trade Unions and Society is a broadside attack on trade unions and on those academics who have brought forward theories which seem to defend them. Trade Unions practise, in the authors words, «organised extortion and industrial strangulation» (p. 133) and constitute «a potential threat to capitalism and democracy» (p. 150).

To arrive at this conclusion the authors take two routes. In the first place, they mount an aggressive attack on that economic and industrial relations literature which appears to defend or justify the existence of trade unions. They hit at the so-called 'Harvard School' of industrial organisation (eg. R.E. Caves and K.B. Clark) who have argued that trade unions provide valuable sociological functions as a "collective voice" and shown that some evidence exists to indicate that trade unions tend to increase productivity. The authors attack the representativity of trade unions and portray union members as trapped and manipulated by self-serving union leaders some of whom "may wish to wreck the capitalist system, others to feather their own nest» (p. 140). On the productivity question, Addison serves up the results of a study of the British coal mining industry 1900-1913 by Pencavel showing reduced productivity as a result of unionisation. But this result should hardly be seen as surprising, since Pencavels study sees a reduced work week and "reduced fear of discipline» as key indicators of lower productivity. (p. 59).

While the authors base their economic analysis in classical paradigms of perfect competition in the labour market, they charge the unions with causing inflation and decreased productivity. This leaves them in a bit of a dilemma, however, for they are forced to admit that their own studies at the micro-economic level, as well as empirical studies done elsewhere do not warrant such a conclusion. Instead the authors revert to a quite different explanation - a political one, to show how trade unions are the principal cause of the British disease.

This is the model of public choice, where the rich and powerful unions hold government (and society) to ransom by their votegetting power. This way unions, by their political pressure, can demand (and get) inflationary government over-spending, abnormal protection of inefficient industries and immunity from normal legal obligations. By their 'capture' of the state, unions may oblige government to follow policies that increase inflation, reduce productivity and slow economic growth.

The authors readily admit that the unions are not the only interest groups to lob- 
by in a self interested way. As they say «other mass lobbies exist; for example, the householder lobby" (p. 17). In point 'of fact, however, throughout the volume the authors concentrate their fire on unions as if they were the only culprits. Furthermore, in this political equation, giant corporations, banks, Boards of Trade or Chambers of Commerce are all but absent.

This is one of the major weaknesses in the credibility of the present volume. Granted the relatively greater rate of unionisation in the United Kingdom, and granted too, the close links between the Labour Party and the Trade Union movement, still is it credible to argue that the state has become a hostage of the labour movement? Certainly no serious scholar or political observer would make such an observation in Canada. It might be argued that US multinationals have undue influence, or that the oil companies have friends in high places, but to seriously argue that the CLC can hold the government of Canada "hostage» takes a vivid political imagination.

Having thus dealt with the social and economic problems which can be laid almost directly at the door of the Trade Union movement, the book then tackles two possible «solutions» to this social dilemma: corporatism and worker self-management. Corporatism is denounced as worse (if possible) than the current situation. It constitutes the taking of the trade union movement into the very bosom of the state, where it will inevitably press for more of the same pernicious policies with even more disastrous effect. This is to be discarded.

John Burton's criticism of Worker SelfManagement on the Yugoslavian or Mondragon models constitute arguably the strongest portion of the next. While the level of economic development makes these models questionable as proxys for an eventual British experiment, the author examines the forces at work in a worker-managed, market-distributed production system. The social and economic effects in terms of entrepreneurship, efficiency, employment and pricing are looked at and should give pause for the advocates of that system in Canada.
In summary, Trade Unions and Society, is more of a diatribe against trade unions in Britain, than a sober analysis of the "British disease». It argues fiercely that trade unions constitute a threat to "democracy» and holds out as its only logical conclusion that the latter must be "deorganised" if capitalism is to be allowed to flourish.

Peter E. LARSON

Conseil de recherches

en sciences humaines du Canada

Labor Arbitration in State and Local Government, by Richard A. Lester, Princeton University, Princeton, New Jersey, 1984, 210 pp., ISSN 0079-5305.

Les relations du travail au sein des secteurs public et parapublic ont suscité beaucoup de difficultés et d'inquiétudes au Québec depuis de nombreuses années. Les conflits se sont multipliés, les négociations collectives ont été non seulement pénibles, mais, à la suite d'arrêts de travail plus ou moins longs et coriaces, il a fallu y mettre fin par des lois spéciales et des décrets qui ont beaucoup mécontenté et ont laissé des blessures difficiles à cicatriser.

La raison en est simple. Les travailleurs du secteur public sont venus massivement au syndicalisme plus tard que ceux de l'entreprise privée, mais une fois le mouvement enclenché, un grand nombre d'entre eux se sont prévalus des avantages que pouvait leur apporter la syndicalisation.

Ce phénomène ne s'est pas produit qu'au Québec et au Canada. Les Etats-Unis l'ont connu également durant la même période, surtout à partir de la décision du président Kennedy en 1962 d'ouvrir aux fonctionnaires du gouvernement de Washington la voie à la négociation de certaines conditions de travail, ce qui a entraîné la multiplication des syndicats aux Etats-Unis à la fois au niveau des États, des comtés, des villes, des conseils scolaires et des organismes sociaux en général. 